\title{
Religious Dimensions of the Self in the Second Century CE
}

\author{
Ed. by Jörg Rüpke and Gregory D. Woolf \\ [Religiöse Dimensionen des Selbst im zweiten Jahrhundert n. Chr.]
}

Veröffentlicht auf Englisch.

Bildet das zweite Jahrhundert n. Chr. eine Zäsur für die Entwicklung von Vorstellungen eines »Selbst«? Wenn ja, weist dieser

Religious Dimensions of the Self in the Second Century CE

Edited by JÖRG RÜPKE and GREG WOOLF

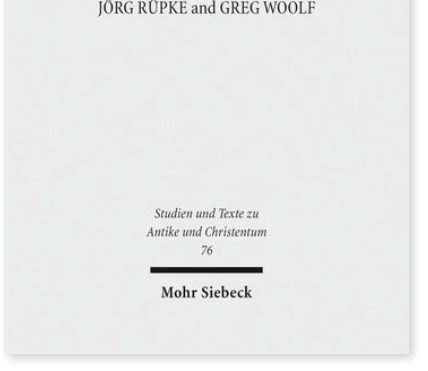

2013. XI, 299 Seiten. STAC 76

ISBN 978-3-16-152351-9

DOI 10.1628/978-3-16-152351-9

eBook PDF $99,00 €$

ISBN 978-3-16-152243-7

fadengeheftete Broschur 99,00€
Prozess eine religiöse Dimension auf? War er mit Veränderungen im Bereich von Praktiken und Institutionen verbunden? Und schließlich: Lassen sich diese Entwicklungen als je eigene Formen von religiöser Individualisierung verstehen? Diesen Fragen widmen sich die Autoren dieses Bandes, Spezialisten für die Philosophie, Theologie, Literatur- und Religionsgeschichte der Epoche. Im Mittelpunkt stehen Texte und Autoren wie Seneca, Plutarch, Epiktet, der »Hirte des Hermas«, Lukian von Samosata, Justin Martyr und Ptolemaeus von Rom und das Corpus Hermeticum. Die Autoren des Bandes zeigen, wie sich Vorstellungen vom »Selbst« mit körperbezogenen Praktiken von Kleidung und Haartracht wie Institutionen ethischer Reflexion und religiöser Erziehung miteinander zu wirkmächtigen Vorstellungen verbinden.

Inhaltsübersicht

Gregory D. WoolfJjörg Rüpke: Introduction Rethinking Philosophical Tradition

Eran Almagor: Dualism and the Self in Plutarch's Thought - Jula Wildberger: Delimiting a Self by God: Epictetus and Other Stoics Religious Concepts of the Self Jörg Rüpke: Two Cities and One Self: Transformations of Jerusalem and Reflexive Individuality in the Shepherd of Hermas - Harry O. Maier: Dressing for Church: Tailoring the Christian Self in Clement of Alexandria - Christoph Markschies: Das 'Selbst' in der Valentinianischen Gnosis - Anders Klostergaard Petersen: Emergence of Selfhood in the Writings of Justin - Anna Van den Kerchove: Self-Affirmation and Self-Negation in the Hermetic Revelation Treatises - Richard Gordon: Innovation, Individuality and Power in Graeco-Roman Religion: The Mystagogue Second Sophistic Perspectives Wolfgang Spickermann: Philosophical Standards and Individual Life Style: Lucian's Peregrinus/Proteus Charlatan and Hero - Dorothee Elm von der Osten: Habitus corporis und Selbstdarstellung in Lukians Alexander oder der Lügenprophet und der Apologie des Apuleius Practices of the Self Zsuzsanna Várhelyi: Selves in Sickness and Health: Some Religious Aspects of Self-Care Among the Imperial Elite - Elena Muñiz Grivaljo: Votive Offerings and the Self in Roman Athens Peter Gemeinhardt: Wege und Umwege zum Selbst: Bildung und Religion im frühen Christentum

Jörg Rüpke Born 1962; permanent fellow in Religious Studies at the Max Weber Centre for Advanced Cultural and Social Studies at the University of Erfurt and co-director of the International research group »Religion and Urbanity: Reciprocal Formations."

https://orcid.org/0000-0002-4173-9587

Gregory D. Woolf Born 1961; 2009-10 Fellow of the Max Weber College of the University of Erfurt; Professor of Ancient History in the University of St Andrews, Scotland; currently holds a Major Research Fellowship from the Leverhulme Trust to investigate the origins of religious pluralism in the Roman World.

Jetzt bestellen:

https://mohrsiebeck.com/buch/religious-dimensions-of-the-self-in-the-second-century-ce-9783161523519?no_cache=1 order@mohrsiebeck.com

Telefon: $+49(0) 7071-923-17$

Telefax: $+49(0) 7071-51104$ 